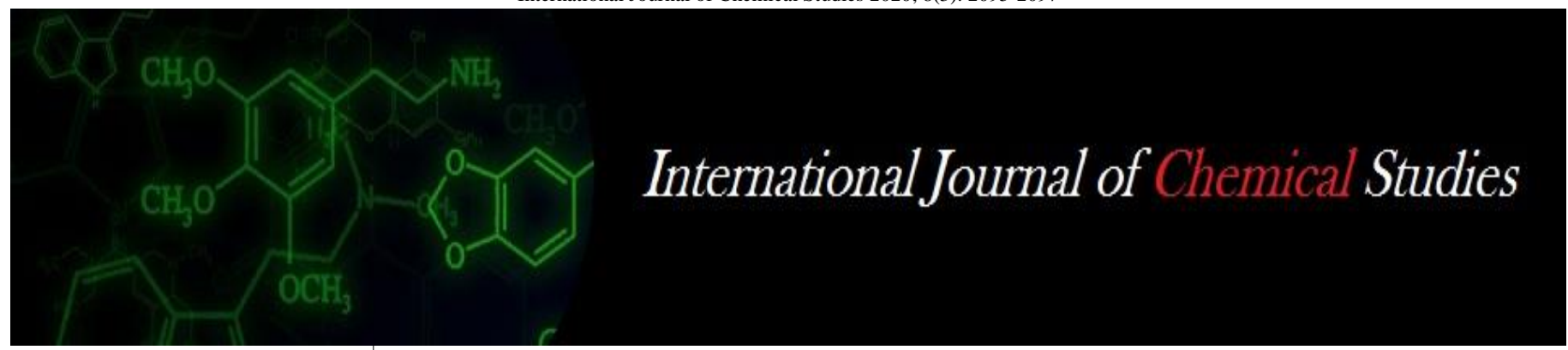

P-ISSN: 2349-8528

E-ISSN: 2321-4902

www.chemijournal.com

IJCS 2020; 8(3): 2095-2097

(C) 2020 IJCS

Received: 22-03-2020

Accepted: 28-04-2020

\section{CB Gawai}

P.G. Student, Animal

Husbandry and Dairy Science,

College of Agriculture, Nagpur,

Maharashtra, India

\section{RM Zinjarde}

Associate Professor, Animal

Husbandry and Dairy Science,

College of Agriculture, Nagpur,

Dr. PDKV, Akola, Maharashtra,

India

\section{Bhavana R Wankhade}

Assistant Professor, Animal

Husbandry and Dairy Science,

College of Agriculture, Nagpur,

Dr. PDKV, Akola, Maharashtra,

India

\section{AB Motghare}

Assistant Professor, Animal

Husbandry and Dairy Science,

College of Agriculture, Nagpur,

Dr. PDKV, Akola, Maharashtra,

India

\section{Utilization of lemongrass (Cymbopogon flexuosus) distillate in the preparation of cow milk lassi}

\author{
CB Gawai, RM Zinjarde, Bhavana R Wankhade and AB Motghare
}

DOI: https://doi.org/10.22271/chemi.2020.v8.i3ac.9517

\begin{abstract}
The present investigation was undertaken to utilize the of lemongrass (Cymbopogon flexuosus) distillate in the preparation of cow milk lassi. The lassi prepared in the proportion of 100:0 $\left(\mathrm{T}_{1}\right)$, 99.5:0.5 $\left(\mathrm{T}_{2}\right)$, 99:1.0 $\left(\mathrm{T}_{3}\right)$, 98.5:1.5 $\left(\mathrm{T}_{4}\right)$ and 98:2.0 $\left(\mathrm{T}_{5}\right)$ lassi to lemongrass distillate were laid out with five treatments and four replications in Completely Randomized Design (CRD). The data revealed that fat, protein, moisture, ash, acidity per cent and $\mathrm{pH}$ value were slightly increased with increase in the levels of lemongrass distillate. The good quality lassi prepared with addition of 2.0 per cent of lemongrass distillate contained 3.31, 2.85, 10.94, 89.06, 0.62, 0.62 per cent and fat, protein, total solids, moisture, ash, acidity and $4.79 \mathrm{pH}$, respectively. The sensory evaluation carried out by the five judges, showed that the lassi prepared by blending with 2 per cent lemongrass distillate $\left(\mathrm{T}_{5}\right)$ had highest score for flavour (40.62 out of 45), body and texture (33.57 out of 35), colour and appearance ( 8.32 out of 10), acidity ( 8.31 out of 10$)$ and the overall acceptability had the highest score ( 8.53 out of 9 ) by 9 point hedonic scale and ranked as the most acceptable treatment. The cost of production of the lassi prepared with 2 per cent of lemongrass distillate in (T5) was Rs. 63.92 per kg which was superiorly accepted by the panel of judges. Hence, it is concluded that the best quality lassi can be prepared by using 2 per cent of lemongrass distillate and 98 per cent of lassi with $15 \%$ sugar.
\end{abstract}

Keywords: Lassi, lemongrass distillate, sensory attributes, cost structure

\section{Introduction}

Fermented milks were developed throughout the world as a means of preserving milk solids against spoilage. According to FSSAI (2006) ${ }^{[2]}$, the fermented milk a product obtained by fermenting milk with permitted ingredient or micro-organisms resulting in lower of $\mathrm{pH}$. It is popular for its pleasant taste, cooling and thirst quenching properties and therapeutic value. Lassi is simply fresh dahi (yogurt) blended with potable water. Lassi is the ultimate probiotic; it provides a natural means of promoting the proper intestinal flora. Lassi is described as a fermented milk beverage obtained after the growth of selected culture, usually lactic streptococci in heat treated whole or partially skimmed milk followed by sweetening with sugar. (Krishna et al. 2013) ${ }^{[9]}$.

Lemongrass (Cymbopogon flexuosus) is a tropical grass native to southern parts of India and Sri Lanka. It yields aromatic oil used as flavoring, and in perfumery and medicine. It is believed to have a wide range of therapeutic effects, and has been used for centuries in South America and India. Lemongrass is reported to be a favorite ingredient in Thai cuisine and dishes. There are several species of lemongrass, but Cymbopogon flexuosus is the variety recommended for medicinal purposes. Only the fresh or dried leaves of lemongrass, and the essential oil derived from them, are used as a drug. Lemongrass is widely used as an essential ingredient in Asian cuisines because of its sharp lemon flavour. Herbal tea of lemongrass is used as sedative as well as immunostimulant in India (Sutariya, 2013) ${ }^{[14]}$.

\section{Materials and Methods}

The utilization of lemongrass (C. flexuosus) distillate in preparation of cow milk lassi was undertaken in the section of Animal Husbandry and Dairy science, College of Agriculture Nagpur, during 2018-19. The lassi prepared in the proportion of 100:0 $\left(\mathrm{T}_{1}\right)$, 99.5:0.5 $\left(\mathrm{T}_{2}\right)$, 99:1.0 $\left(\mathrm{T}_{3}\right)$, 98.5:1.5 $\left(\mathrm{T}_{4}\right)$ and 98:2.0 $\left(\mathrm{T}_{5}\right)$ lassi to lemongrass distillate and sugar was added @ $15 \%$ in all treatments.
Corresponding Author:
Bhavana R Wankhade Assistant Professor, Animal Husbandry and Dairy Science, College of Agriculture, Nagpur Dr. PDKV, Akola, Maharashtra India 
The flow chart for preparation of lemongrass distillate lassi is given as below.

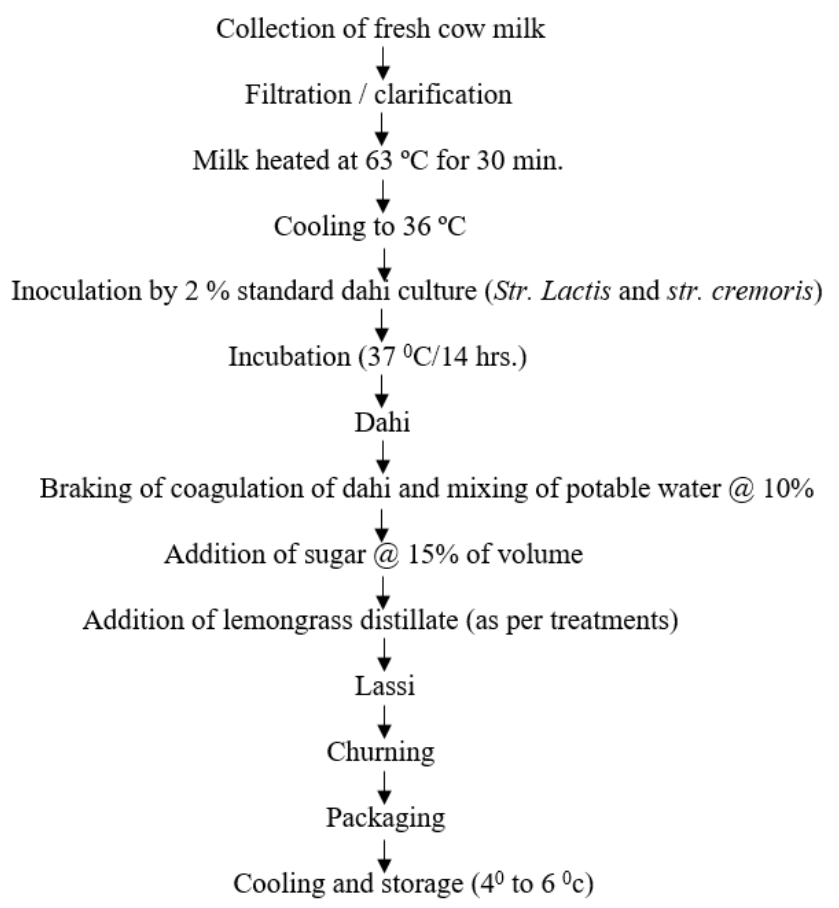

Fig 1: Flow chart for preparation of lemongrass distillate lassi

The product was subjected to chemical analysis the fat (by
Gerber's method, SP: 18 part XI (1981), total solids (by gravimetric, SP. 18 part XI (1981), acidity (IS:1479, Part I (1961) ${ }^{[5]}$, protein (by macro-kjeldahl method, IS: 1479Part II (1961) ${ }^{[5]}$, ash (SP: 18 part XI (1981)., pH (by digital pH meter) and moisture was determined by subtracting the total solid content from 100 in the sample.

The quality lemongrass distillate lassi was judged by sensory evaluation by offering the sample to the panel of 5 judges by score card method suggested by Pal and Gupta (1985) ${ }^{[1]}$ and overall acceptability by 9point hedonic scale (Nelson \& Trout, 1964).

The experiment was laid out in completely randomized design (CRD) with 5 treatments and 4 replications. The data obtained were analyzed statistically according to method described by Snedecor and Cochran (1994).

\section{Results and Discussion}

\section{A) Physico-chemical composition of lemongrass distillate lassi}

The finished product of lemongrass distillate lassi were subjected for the proximate analysis viz., fat, total solids, acidity, protein, ash, $\mathrm{pH}$ and moisture. The results obtained on account of these parameter are presented in Table 1 revealed that the effect of different levels of lemongrass distillate on physico-chemical attributes were found to be non-significant. The similar results were reported by Swati Bagal (2011) ${ }^{[15]}$ in papaya pulp lassi, Matkar (2010) ${ }^{[10]}$ in papaya pulp lassi, Jyoti Gaikwad (2018) ${ }^{[8]}$ in menthol juice and Pardhi et. al. $(2014)^{[12]}$ in finger millet flour lassi.

Table 1: Effect of different levels of lemongrass distillate on physico-chemical attributes of lassi (per cent).

\begin{tabular}{|c|c|c|c|c|c|c|c|}
\hline Treatments & Fat & Protein & Total Solids & Moisture & Ash & Acidity & pH \\
\hline $\mathrm{T}_{1}$ & 3.38 & 2.91 & 11.18 & 88.82 & 0.64 & 0.64 & 4.69 \\
\hline $\mathrm{T}_{2}$ & 3.36 & 2.89 & 11.12 & 88.88 & 0.63 & 0.63 & 4.71 \\
\hline $\mathrm{T}_{3}$ & 3.34 & 2.88 & 11.06 & 88.94 & 0.63 & 0.63 & 4.74 \\
\hline $\mathrm{T}_{4}$ & 3.33 & 2.86 & 11.00 & 89.00 & 0.63 & 0.63 & 4.76 \\
\hline $\mathrm{T}_{5}$ & 3.31 & 2.85 & 10.94 & 89.06 & 0.62 & 0.62 & 4.79 \\
\hline S.E. \pm & 0.006 & 0.02 & 0.03 & 0.03 & 0.011 & 0.004 & 0.008 \\
\hline Results & NS & NS & NS & NS & NS & NS & NS \\
\hline
\end{tabular}

\section{B) Sensory evaluation of lemongrass distillate lassi}

The data with respect to sensory evaluation of lemongrass distillate lassi are presented in Table 2 and showed that lassi prepared by using 2 per cent lemongrass distillate $\left(\mathrm{T}_{5}\right)$ scored highest rank for flavour (40.62 out of 45), body and texture (33.57 out of 35), colour and appearance (8.32 out of 10), acidity (8.31 out of 10) and overall acceptability score (8.56 out of 9). Similar were reported by Tambe (2017) ${ }^{[16]}$ in lassi prepared with different levels papaya pulp, Avtade (2007) ${ }^{[1]}$ in lassi prepared with mango pulp and pomegranate juice and Matkar (2010) ${ }^{[10]}$ in papaya pulp (14\%) lassi.

Table 2: Overall average sensory score of lassi as affected by different levels of lemongrass distillate.

\begin{tabular}{|c|c|c|c|c|c|}
\hline Treatments & Flavor (45) & Body \&Texture (35) & Colour \& Appearance (10) & Acidity (10) & Overall acceptability (by hedonic scale) \\
\hline $\mathrm{T}_{1}$ & $33.85^{\mathrm{e}}$ & $27.57^{\mathrm{e}}$ & $7.56^{\mathrm{e}}$ & $7.56^{\mathrm{e}}$ & $6.05^{\mathrm{e}}$ \\
\hline $\mathrm{T}_{2}$ & $35.44^{\mathrm{d}}$ & $29.08^{\mathrm{d}}$ & $7.59^{\mathrm{d}}$ & $7.60^{\mathrm{d}}$ & $6.58^{\mathrm{d}}$ \\
\hline $\mathrm{T}_{3}$ & $36.38^{\mathrm{c}}$ & $31.27^{\mathrm{c}}$ & $7.95^{\mathrm{c}}$ & $7.94^{\mathrm{c}}$ & $7.62^{\mathrm{b}}$ \\
\hline $\mathrm{T}_{4}$ & $38.57^{\mathrm{b}}$ & $31.92^{\mathrm{b}}$ & $8.08^{\mathrm{b}}$ & $8.06^{\mathrm{b}}$ & $8.59^{\mathrm{c}}$ \\
\hline $\mathrm{T}_{5}$ & $40.62^{\mathrm{a}}$ & $33.57^{\mathrm{a}}$ & $8.32^{\mathrm{a}}$ & $8.31^{\mathrm{a}}$ & 0.12 \\
\hline S.E. $(\mathrm{m}) \pm$ & 0.15 & 0.09 & 0.05 & 0.04 & 0.36 \\
\hline C. D. at 5\% & 0.46 & 0.27 & 0.15 & 0.13 & Sig. \\
\hline Results & Sig. & Sig. & Sig. & Sig. & \\
\hline
\end{tabular}

\section{C) Cost of production of lemongrass distillate lassi}

Lassi prepared with addition of lemongrass distillate at $0\left(\mathrm{~T}_{1}\right)$, $0.5\left(\mathrm{~T}_{2}\right), 1.0\left(\mathrm{~T}_{3}\right), 1.5\left(\mathrm{~T}_{4}\right)$ and 2.0 per cent $\left(\mathrm{T}_{5}\right)$ were Rs. 58.12, Rs. 59.57, Rs. 61.02, Rs. 62.47 and Rs. 63.92, respectively. The cost of production of lassi prepared with 2.0 per cent lemongrass distillate $\left(\mathrm{T}_{5}\right)$ was found to be Rs. 63.92 per $\mathrm{kg}$ which is best treatment selected by judges by sensory evaluation. Similar result was reported by Swati Bagal (2011) ${ }^{[15]}$ in papaya pupl lassi.

\section{Conclusion}

Hence, it is concluded that the best quality lassi can be prepared by using 2 per cent of lemongrass distillate and 98 per cent of lassi with $15 \%$ sugar. 


\section{References}

1. Avtade NB. Utilization of pomegranate juice in the preparation of lassi M.Sc. (Agri), Thesis (Unpub.) Dr. P.D.K.V, Akola, 2007.

2. FSSAI. Food safety and standards act, No.34 of 2006, Legislative Department, ministry of law and justice, New Delhi, 2006.

3. IS: 1166 (Part I). Method of test for Dairy industry, Chemical analysis of milk. Indian Standard Institute, Manak Bhavan, New Delhi, 1973.

4. IS: 1479 (Part I), Method of test for dairy industry, chemical analysis of milk. Indian Standard Institute, Manak Bhavan New Delhi, 1960.

5. IS: 1479 Part-II. Method of test for dairy industry: Chemical analysis of milk. Indian Standard Institution, Manak Bhavan, New Delhi, India, 1961.

6. IS:1165. Indian standard specifications for milk powder (whole and skim). Indian Standards Institute, Manak Bhavan, New Delhi, 1967.

7. IS:1224 Part-I. Determination of fat by Garber's method (Revised Indian Standard Institution), Manak Bhavan, New Delhi, India, 1977.

8. Jyoti Gaikwad R. Utilization of menthol (Menth arvensis) juice for the preparation of from cow milk. M. Sc. (Agri.) Thesis (Unpub.) Dr. P. D. K. V., Akola, 2018.

9. Krishna M, Venkateshaiah BV, Prabha R. Development of reduced sugar probiotic lassi. Asian J Dairy and Food Res. 2013; 32(1):79-82.

10. Matkar SP. Studies on effect of fruit additives on microbial status of lassi with special references to lactic acid bacteria. Ph. D. Thesis (Unpub.) MPKV, Rahuri, 2010.

11. Pal D, Gupta SK. Sensory evaluation of Indian milk products. Indian Dairyman. 1985; 37(10):465-474.

12. Pardhi PS, Desale RJ, Mule PR, Ghule BK, Tambe DR, Gavhane MS. Studies on finger millet lassi. Asian J Dairy and food Res. 2014; 33(4):255-258.

13. Snedecor GW, Cocharn WG. Statistical method, $8^{\text {th }}$ edition Oxford and BIS publishing company, Culcutta, 1994.

14. Sutariya H, Rao J. Utilization of lemongrass distillate in the preparation of lassi. N.D.R.I Southern regional station. Aadugody Bangalore, 2013, 20-26.

15. Swati Bagal V. Utilization of papaya pulp for lassi preparation. M. Sc. (Agri), Thesis (Unpub.) Dr. P.D.K.V., Akola, 2011.

16. Tambe NN. Preparation of papaya (Carica papaya L.) pulp lassi from buffalo milk. M. Sc. (Agri.), Thesis (Unpub.) Dr. P. D. K. V., Akola, 2017. 